\title{
Pósa Fanni
}

\section{AZ ARCHÍVUMI FORDULAT ÉS A KRITIKAI KULTÚRAKUTATÁS \\ A COURAGE MINT PROJEKT ÉS DIGITÁLIS ADATBÁZISA \\ DOI 10.35402/kek.2020.3.10}

\begin{abstract}
Absztrakt
A hetvenes évek kulturális fordulata magával vonta többek között az archívumok átalakulását is. Emellett a digitális fordulatnak köszönhetően kialakult egy újfajta hozzáférhetőség, melynek leírására a láthatóság fogalmát használom. Tanulmányomban bemutatom, milyen körülmények hívták elő a bekövetkezett változásokat, illetve melyek a legfóbb jellemzői ennek az új archívumnak - mindezt a COURAGE projekt digitális adatbázisán, a Registry-n keresztül vizsgálom. A COURAGE projekt a huszadik században jelen lévő kulturális ellenállás különböző formáit térképezte fel 16 posztszocialista ország, köztük Magyarország esetében, mindezt kultúrafókuszú megközelítéssel. Vizsgálatom tárgya az archívumhasználat mellett a projekt módszertana, a kritikai kultúrakutatás relevanciája a kortárs kulturális/tudományos színtéren.
\end{abstract}

\begin{abstract}
The cultural turn of the 1970s involved, among other things, the transformation of archives. In addition, due to the digital turn, a new kind of accessibility has emerged, which I refer to as visibility. In this paper I present the circumstances that led to these changes, also what are the main features of this new type of archive - all through the examination of the Registry, the digital database of the COURAGE project. The COURAGE project mapped the various forms of the twentieth century's cultural opposition in 16 post-socialist countries, including Hungary - all with a culturefocused approach. In addition to the usage of archives, the subject of my research is the relevance of the cultural studies in the contemporary cultural/ scientific scene.
\end{abstract}

\section{Bevezetés}

A huszadik században végbemenő paradigmaváltás, azaz a kulturális fordulat alapjaiban változtatta meg a humán- és a társadalomtudományokat, hiszen egyfajta kultúrafókuszú beállítódás vált általánossá. Ebből kifolyólag óriási hatással volt a múlthoz való viszonyunkra, valamint magára a hivatalos, intézményesült kollektív emlékezetre is - mindez pedig egy új típusú archívum kialakulásához vezetett. Vajon miben áll ez az új archívum? Milyen körülmények tették lehetővé, ha nem épp szükségszerüvé a bekövetkezett változásokat a régi típusú archívumhasználathoz képest? Többek között ezekre a kérdésekre keresem a választ a COURAGE projekt vizsgálatával.

A COURAGE az Európai Unió eddigi legnagyobb kutatási és innovációs programjához, a Horizon2020-hoz kapcsolódóan indult 2016ban. A három évig tartó projekt átfogó vizsgálata összesen 16 országra terjedt ki, amely a huszadik századi kulturális ellenállás különböző formáira fókuszált a posztszocialista országok esetében. A kánon és a hivatalos kultúra megkérdőjelezése ezekben az országokban igen sokszínű demokratizálódáshoz vezetett, amely sok értelemben és formában van jelen - gondolhatunk itt például a vizsgálódás középpontjának a perifériára szorult kulturális jelenségekre való kiterjedésére, a kultúrafókuszú megközelítésre. ${ }^{2}$ Megfigyelhető továbbá egy újfajta hozzáférhetőség, amelyet az egyszerűség kedvéért a láthatóság fogalmával jelölök majd. Ennek egyik lényeges formáját, az úgynevezett digitális fordulat hatásait vizsgálom a COURAGE projekt elektronikus adatbázisát bemutatva.

Írásomban azt igyekszem tehát minél alaposabban és részletesebben körüljárni, hogyan működik

1 Lásd még: https://ec.europa.eu/programmes/horizon 2020/en/what-horizon-2020

2 Az ilyen és az ehhez hasonló kezdeményezések alapozták meg az Európai Unió legújabb, 2018-as kulturális stratégiáját. Lásd még: http://data.consilium.europa.eu/ doc/document/ST-13948-2018-INIT/en/pdf\#http:// data.consilium.europa.eu/doc/document/ST-139482018-INIT/en/pdf, különösen 5, 9-11. 
a COURAGE adatbázisa mint regiszter, fóként felépítésére és a hozzá kapcsolódó kutatás módszertanára. Vizsgálatom tárgya továbbá a projekt egésze által képviselt kultúrafókuszú megközelítés, illetve a kritikai kultúrakutatás relevanciája a kortárs kulturális perspektívából kiindulva.

\section{COURAGE és a kritikai kultúrakutatás - a kultúrafókuszú megközelítés}

A COURAGE vizsgálta többek között magának az adatgyüjtésnek és a dokumentációnak az államszocializmus alatti gyakorlatát - azt, hogy milyen funkciót töltenek be a vizsgált gyüjtemények a rendszerváltás előtt és után -, valamint körüljárta a feldolgozott archívumok által közvetített taktilis kultúrát, azaz miért éppen ezek a tételek kerültek megőrzésre. Felvázolta mindennek elvi hátterét, hogy milyen módon és mi alapján történt maga az anyaggyüjtés és a dokumentáció. Vizsgálta továbbá a gyűjteményeket kezelő intézményeket, valamint a tágabb kontextusban és viszonyrendszerben betöltött helyüket és szerepüket. A COURAGE projekt teljes egésze, így a digitális adatbázisa is a kritikai kultúrakutatás megközelítési módszereire épül. Ez minden eredménye mellett emiatt is jelentős, hiszen komplex és sokoldalú kezdeményezésként, a kulturális ellenállás mintázatait vizsgálva hirdeti a kultúrafókuszú megközelítési mód fontosságát. Az ellenkultúra lenyomatait prezerváló archívumokat gyűjtötte össze, eredetüket vizsgálja és elemzi interdiszciplináris megközelítéssel - mind kulturális, szociális és politikai összefüggéseikben. Magának a projektnek fö célkitüzése, hogy a feldolgozott archívumokat minél szélesebb közönséghez juttassa el, ezáltal elősegítve ezek társadalmi/kulturális jelentöségének növekedését.

Bár ez a kutatási módszer hazánkban még nem intézményesült és az ilyen megközelítés mind a mai napig igencsak marginálisnak számít, az Európai Unió kulturális politikáját már releváns mértékben hatja át. A COURAGE projekt ismertetése és elemzése többek között ezért is bír különös relevanciával föként magyarországi, de nemzetközi összefüggésben is.

A következőkben azokat a körülményeket mutatom be, amelyek lehetővé és szükségszerűvé tették a kritikus, kultúrafókuszú vizsgálódást, illetve, hogy miért ez a megfelelő módszertan a különböző kulturális-művészeti jelenségek, többek között a civil ellenállás vizsgálatához is.

\section{A kulturális fordulat és hatásai}

A késő-modernitást követő, 1970-es években bekövetkezett posztmodern fordulat a minden addigi kánon és szabályszerűség megkérdőjelezését jelentette. A kultúra mind fogalomként, mind pedig perspektívaként az elméleti, teoretikus vizsgálódás középpontjába került. Az emlékezés mint kollektív, kulturális entitás is átalakulásokon ment át az elmúlt néhány évtized során. Az egyéntől a különböző csoportosulásokon át (ideértve az etnikai, vallási, politikai stb. csoportokat) az egészében vett társadalmakig és országokig minden téren átalakult a múlthoz való, addig hagyományosnak tekintett viszony. Ezek az átalakulások több formában jelentkeztek: ilyen volt például a történelemírás intézményének kritikája és megkérdőjelezése, a korábban perifériára került szubkultúrák vagy társadalmi csoportok elötérbe kerülése (pl. feminista, posztkolonialista megközelítések elterjedése), a kanonikus, hivatalos kultúra-, művészet- és történelemfelfogás kikezdése, valamint az örökség különböző formái, így a múzeumok, archívumok, genealógiai kutatások iránti megnövekedett érdeklődés (András 2009).

A posztmodern fordulat okozta demokratizálódás megjelenésével minden értelemben elmosódtak a tiszta "határvonalak” (pl. interdiszciplináris megközelítések megjelenése, periféria feltérképezése, kánon megkérdőjelezése, intézménykritika, magasés populáris kultúra relációjának felülvizsgálata). Egyre nagyobb hangsúly kerül az olyan, a hivatalos kánon számára marginális kulturális csoportosulásokra és jelenségekre, amelyek a kulturális fordulat előtt a hivatalos tudományos perspektívából jelentéktelennek minősültek. Ezek az átalakulások vezettek többek közt a cultural studies, azaz a kritikai kultúrakutatás tudományterületének kialakulásához.

\section{A kritikai kultúrakutatás mint adekvát megközelités}

A következőkben fontosnak tartom megvizsgálni, mit értünk hazánkban a kritikai kultúrakutatás fogalmán, illetve körüljárni a magyarországi diszciplína helyzetét. Mindezt remekül foglalja össze Havasréti József $A$ kaleidoszkópon kivüllbelül - a kritikai kultúrakutatás Magyarországon (2005) címü cikke. Meglátása szerint a kritikai kultúrakutatás legfóbb célja a perifériára szorult csoportok kultúrájának vizsgálata a szembehelyezkedés jelenségein 
keresztül. Abból indul ki, hogy a kritikai kultúrakutatás elterjedése egyfajta kortünetként is felfogható, hiszen minden esetben a kortárs kultúrára, tehát egy bizonyos szempontból önmegértésre reflektál. Fontosnak tartom kiemelni Havasréti szövegéből a diszciplína fogadtatásának töredékességét - töredékes abban az értelemben, hogy a külföldön már módszertanná érett megközelítés átvétele nem történt meg teljes egészében, hanem csupán az adott tudományterülethez vagy kutatási témához illeszkedő tendenciák és vonatkozások tudnak itthon meghonosodni - ezek is csak abban az esetben, ha ezt megelözően már létezett hozzá kanonizált „előzmény". Havasréti úgy fogalmaz, hogy valójában a régi és az új tudományos kontextusok összeolvadásaként is felfoghatjuk. Így az sem meglepő, hogy a terület kutatói mind-mind egyfajta „vendégstátuszban" működnek, azaz valamely más tudományterületről látogatnak át (Havasréti 2005).

Magyarországon tehát még mindig nem intézményesült a kritikai kultúrakutatás mint diszciplína - ezt jelzi az is, hogy Dessewffy Tibor Alice Csodaországban, avagy a kultúrakutatás a huszonegyedik században (1996) című cikkében három fontos kérdésfeltevéssel járja körbe: (1) mi vezetett a kialakulásához, (2) melyek a legfontosabb területei, (3) mi a jelentősége közép-kelet-európai terepen. Írásának fő konklúziója, hogy a kritikai kultúrakutatás több szempontból is egy emancipatorikus szociológiai megközelítést képvisel: a magaskultúra mellett populáris, a többségin felül pedig az „alternatív", kisebbségi kultúrát, a szubkultúrákat is a vizsgálódás ernyője alá vonja. ${ }^{3}$

Vörös Miklós és Nagy Zsolt a Replikában megjelent Kultúra és politika a mindennapi életben (1995) címü cikkében pedig a szerzópáros megalkotta a kritikai kultúrakutatás véleményem szerint legpontosabb definícióját: „[...] a kritikai kultúrakutatás a kultúra és a politika összefonódásának kutatása a mindennapi életben. [...] Minden társadalom kitermel hegemón szerepű kultúrákat, melyek kanonizált szövegekből, viselkedési szabályokból, bevett problémamegoldási gyakorlatokból, a verbális és nem-verbális kommunikáció elfogadott modelljeiből és mindezek átértékelésének lehetőségéből tevődnek össze" (Vörös-Nagy 1995:154). Szerintük a kulturális és politikai jelenségek több különböző szálon is összekapcsolódnak, a kultúrakutatás célja

3 Lásd még: Kunt Ernő - Szarvas Zsuzsa 1993 A komplex kultúrakutatás dilemmái a mai Magyarországon. Miskolci Egyetem Kulturális és Vizuális Antropológiai Tanszéke, Miskolc. pedig, hogy rávilágítson ezekre az összefonódásokra. E tudományág vizsgálódásainak fó tárgya a hatalom által természetesként elfogadtatott, úgynevezett hivatalos kultúra, a diktatórikus rezsim által közvetített értékek, valamint az ezekkel szemben létező stratégiák és kulturális jelenségek.

Ez a megközelítési mód természetesen nemcsak a múlt század kulturális jelenségeinek feldolgozásához elengedhetetlen - Túry György szerint a kritikai kultúrakutatás a legjobb eszköz a kortárs valóság kultúraközpontú vizsgálatára: „Ez a diszciplína akkor és azért jöhetett létre, és amiért a fentiekben vázolt változások szükségszerűvé tették megszületését: olyan horderejű változásokat kell(ett) leírni és értelmezni, amelyek új és másfajta szemlélet és eszközrendszer létrehozását követelték meg. [...] A diszciplína arra ad tehát lehetőséget, hogy a kortárs valóság adott kontextusában értelmezni tudjuk azokat a jelenségeket, amelyek éppen az elmúlt évtizedek során kerültek felszínre, illetve - sok esetben - váltak meghatározó jelentőségűvé" (Túry 2016:115). Látható tehát, hogy a jelen kulturális tényezőinek érdembeli megfigyeléséhez itthon is szükség lenne a kanonizációjára.

\section{A láthatóság kialakulásának fontossága - a civil ellenállás kultúrafókuszú vizsgálata}

A COURAGE projekt komponenseinek vizsgálata folyamán ehhez fontosnak tartom a láthatóság fogalmának használatát. Ez azért szükséges, mert úgy gondolom, hogy a hozzáférhetőség nem fedi le teljes egészében azt a jelenséget, amelyet bemutatni kívánok. A lényegi különbség számomra abban áll, hogy a hozzáférhetőség mindig is jelen volt, hiszen a legtöbb esetben publikus, mindenki számára elérhető gyűjteményekről beszélünk. Most viszont sokkal inkább arról van szó, hogy mindezek egy új szintre, ,awareness"-szerű jelenlétre emelődnek mint korábban perifériára szorult kulturális, társadalmi és művészeti jelenségek. Általánosságban igaz, hogy hiába a hozzáférhetőség, hogyha a nyilvánosságnak nincsen róla tudomása (legyen az a célközönség, az érintett szakma képviselői, vagy akár egy tágabb értelemben vett publikum).

Az civil ellenállást megőrző mintázatokat és ellenarchívumokat vizsgáló COURAGE 16 ország tematikailag releváns gyűjteményeit dolgozza fel kivételesen komplex módon. Nem csupán deskriptív és illusztratív kutatást végez, hanem ezeknek a szélesebb közönség felé való eljuttatása is missziója. 
Mindent hihetetlenül összetett módon, számos komponensével teszi, amelyek önmagukban is releváns kezdeményezések lehetnének. Először is a projekthez tartozik egy „használati utasítás” - a Handbook, azaz a Kézikönyv sokszerzős tanulmánykötet, amely analitikus részletességgel járja végig a kezdeményezés legfőbb célkitűzéseit, módszertanát és a projektben résztvevő országokhoz kapcsolódó archívumok sajátosságait. A kötet tárgyalja továbbá a civil kurázsi összetettségét és örökségét a gyüjtemények szemszögéből, valamint különféle javaslatokat nyújt a posztszocialista blokk vizsgálatának megújítására. Ahogyan az egész projekt, így ez a könyv is igyekszik kiemelni a kulturális ellenállás azon értékeit, amelyek az úgynevezett pán-európai kultúrára jellemzők: a demokratikus részvétel, a civil ellenállás, a szolidaritás, illetve a kulturális diverzitás (Apor és mtsai 2018) - mindezt úgy, hogy egyfajta kapaszkodót nyújt közben a projekt további részeire vonatkozóan.

A projekt másik, számomra különösen kedves összetevője - a szakmai gyakorlatom helyszíne - a Kockázatos tényezők címet viselő utazókiállitás volt. Az első állomás a Fuga Építészeti Központban kapott helyet - a kiállítás 2018. június 14-én nyílt meg és egy hónapon át volt megtekinthető, ezután körbeutazta azokat a posztszocialista országokat, amelyek gyűjteményei feldolgozásra kerültek.

A koncepció alapja a kulturális ellenállás mint heterogén jelenség bemutatása volt - erre utalt a kiállítás három fó részre osztottsága is: (1) Ütközések, (2) Rejtekutak, valamint (3) Kijáratok és párhuzamos világok. Így tehát a kiállított elemek között szerepeltek a hivatalos kultúrához, az úgynevezett első nyilvánossághoz képest létrejött alternatívák különböző formái: egyrészt a nyílt szembenállás, a titokban szerveződés, valamint az úgynevezett „hétköznapi ellenállás” példái is, amelyek nem a közvetlen konfrontációban, hanem az elhatárolódásban mutatkoztak meg. ${ }^{4}$ Ami az installációt illeti, a „[k] iállítás elrendezése: nyitva hagyottságot, a kritika, kiegészítés és átrendezés lehetőségét akartuk hangsúlyozni"5 - magyarázta Kovács Éva szociológus, az MTA Társadalomtudományi Kutatóközpont tudományos tanácsadója. A kiállítás kurátora, Erőss Nikolett pedig így fogalmazott: „[e]lsősorban történetekkel dolgoztunk, ezek azonban a kiállításokban leginkább vizuális(abb) médiumok segítségével

4 Lásd még: http://cultural-opposition.eu/courage/ exhibition?lang=hu

5 A teljes interjúért lásd még: https://magyarnarancs. hu/lokal/keszul-mar-a-tananyag-is-112347 szólalnak meg - egy archívum esetében lényegesen nehezebben bonthatóak ki. A látogatónak kétségkívül sok olvasnivalója akadt, de a kiállítás struktúrája kedvezett annak, hogy mindenki annyit tekintsen meg belőle, amennyire lehetősége van, nem volt egy olyan mesternarratíva, amelynek követése nélkül elveszünk". ${ }^{6}$ A létrejövő adatbázis ilyen módon „display”-re állítása - bár foként a szakmabelieket célozza meg - véleményem szerint nagyban elősegítette a civil ellenállás témájának láthatóságát, dialógust nyitva a hozzáértő közönség tagjai között.

A már említett történetmesélésnek egy másik eszköze a COURAGE-PAREVO Nemzetközi Dokumentumfilm-fesztivál volt. Az utazókiállításhoz hasonlóan ez az esemény is több helyszínen, köztük a brüsszeli European Research Council épületében is megrendezésre került. A bemutatott filmek olyan témákat érintettek, mint a „szamizdat és cenzúra, budapesti punkok, Chuck Norris román női hangon, falra festett törpék Lengyelországban és a '68-as generáció. Azok a régi történetek, amelyekről nem szoktunk beszélni. Azok, amelyek nemcsak egy generáció, hanem fél Európa életét megváltoztatták" . $\mathrm{Az}$ audiovizuális formában valamivel könnyebben fogyasztható történetek segítettek abban, hogy egyszerre, egy térben, több korosztálynak is át tudják adni a civil ellenállás lenyomatainak és hatásainak relevanciáját a kortárs kulturális kontextusra nézve.

A projekten dolgozó szakemberek emellett számos (tematikusan kapcsolódó) tananyagot ${ }^{8}$ is öszszeállítottak. A középiskolás diákoknak szóló leckék ábrákkal és további segédanyagokra mutató linkekkel teletüzdelt leírásból, a témához kapcsolódó játékokból, valamint tanári segédletből állnak össze. Ez utóbbi részletezi, milyen kompetenciákat sajátíthatnak el a diákok, valamint feldolgozást segítő feladatok is szerepelnek benne. Az egyetemisták számára készült tananyagok sokkal komplexebben épülnek fel - a téma rövid leírását esetenként a Kézikönyv vonatkozó részeire mutató link, audiovizuális segédlet, kötelező és ajánlott irodalom, valamint a digitális adatbázis kapcsolódó elemeinek listája, végül az órán és órán kívül megoldandó feladatok követik. A fiatalabb generáció megszólítása, az interaktivitás megteremtése nagyon fontos szerepet játszik a kultúrafókuszú vizsgálódásra való igény megteremtésében.

6 A teljes interjút lásd: https://www.magyarmuzeumok. $\mathrm{hu} / \mathrm{cikk} /$ courage-gyujtemenyek-halozata

7 http://hu.cultural-opposition.eu/activities/ film-festival/

8 Lásd még: http://hu.cultural-opposition.eu/learning/ 
Ha már interaktivitás, nem lehet nem megemlíteni a COURAGE honlapján elérhető játékokat ${ }^{9}$ sem. Legyen szó összepárosításról, személyiségtesztről vagy memóriajátékról, az edukáció és az úgynevezett játékosítás (gamification) összekapcsolása elősegíti az élvezetes formában játékos tanulást, minden korosztálynak.

A COURAGE központi része a digitális adatbá$z i s,{ }^{10}$ azaz a Registry, amelynek fó funkciója, hogy a feldolgozott gyüjtemények, történetek könnyen használható módon, online elérhetőek és hasznosak legyenek mind a szakmabeliek, mind pedig a nagyközönség számára. Mindehhez képzési napokkal is hozzájárultak a projekt résztvevői: „[...] tájékoztatnak a COURAGE-adatbázis használatának elönyeiről; tanácsokat adnak a gyüjtemények eredményes felhasználásához az oktatásban; támogatják a gyűjtemény fenntartóit abban, hogyan képviseljék magukat még hatékonyabban a hazai és nemzetközi kulturális és tudományos pályázatok, illetve nemzetközi kiállítások segítségével"11 - írják.

A projekt komplexitása és alkotórészeinek sokszínűsége pontosan tükrözi a kulturális ellenállás heterogenitását és összetettségét. Összességében megállapítható, hogy e komponenseknek köszönhetően a COURAGE eredményei rengeteg réteghez eljutnak a láthatóság jegyében - mind demográfiai, mind pedig szakmai értelemben. Tanulmányom további részében a projekt központi részére, az adatbázisra fókuszálok. Kitérek az archívumi és a digitális fordulatra, a Registry felépítésére és működésére, valamint a kortárs kultúrában való relevanciájára is.

\section{A Registry}

\section{Archivumi fordulat}

Vajda András $A z$ archivum mint a kulturális emlékezet és az örökségképzés szintere címủ tanulmányában (2017) az emlékezés, a kulturális értelemben vett örökség és az archívumok közötti relációkat vizsgálta. Ez a vizsgálódás azért is különösen aktuális, mert mint írja, ez a három jelenség több tudományos diszciplína érdeklődését is felkeltette az elmúlt évtizedekben. Vajda írásában (az archívumokat illetően) az intézményi szinten, illetve a használatban bekövetkezett változásokat is

9 Lásd még: http://cultural-opposition.eu/games/

10 Lásd még: http://hu.cultural-opposition.eu/registry/

11 http://hu.cultural-opposition.eu/\#project tárgyalja. Bevezeti a domesztikáció fogalmát - hiszen az archívum nemcsak továbbítja az információkat, hanem értelmezi is azokat. Rámutat arra is, hogy bár a gyűjtemények száma folyamatosan nő, ez számos negatív következménnyel jár: az archívumok „felhígulnak” és inflálódnak, valamint a fragmentálódás megkérdőjelezi a mindenkori célkitűzéseiket és relevanciájukat is. Összességében arra a következtetésre jut, hogy az új típusú archívum a múlt értelmezésében egy, a hagyományostól eltéro” rendszer, emellett ,az adatok több szempont szerint egymás mellé rendezhető és visszakereshető adatbázisba rendezése" érdekében érvel. ${ }^{12}$

A Vajda által kiemelt átalakulásokat fontosnak tartom kiegészíteni a posztmodern paradigmába átlépés különböző hatásainak vizsgálatával. Véleményem szerint a modernizmus archívumait leíró, foucault-i hatalomelmélet feloldódik az új posztmodern, kultúrafókuszú, demokratizáló paradigmában. Ebben a már említett fragmentáltság vált a természetesnek elfogadott létmóddá - úgy látom, társadalomként már nem áltatjuk magunkat, hogy teljes képet tudnánk alkotni, bármiről is legyen szó. Erre a folyamatos hiányérzetre az egyik legáltalánosabb reakcióként a reflex-szerű, kényszeres kitöltést és/vagy módosítást figyeltem meg. Az átalakítás és az ezáltal létrejövő az új típusú archívum meglátásom szerint albumszerü13 ${ }^{13}$ albumszerű olyan értelemben, hogy bizonyos szempontok szerint válogatott elemekből, előre meghatározott struktúra alapján épül fel, ugyanakkor „igény szerint” szabadon átalakítható, módosítható, bővíthető vagy éppen szükíthetö. Az album az én értelmezésemben nyitott (lehetővé teszi és elősegíti a demokratizálódás folyamatát), moduláris szerkezetéből adódóan szabadon szerkeszthető, élő (szinte organizmus), valamint felértékelődik benne az identitás vizsgálata tehát érvényesül benne a Vajda által is kiemelt több szempont szerinti elrendezhetőség és visszakereshetőség. Mindezt figyelembe véve úgy gondolom,

12 „Ez a gondolat Gagyi Józseftől származik, aki a konferencián egyik hozzászólásában világított rá arra a tényre, hogy egy szemléletbeli különbség tapintható ki a két eltérő gyakorlat mögött, hogy míg az erdélyi történettudomány a Székelyföld múltjának feltárását és közzétételét egy három kötetes monográfia formájában képzeli el, addig a néprajztudomány képviselői - elsősorban a Kriza János Néprajzi Társaság keretében - ugyanerre a célra az adatbázisba rendezés formáját választották." - Vajda megjegyzése (2017:24).

13 Marianne Hirsch is használja az album fogalmát, de nála ez inkább a személyes vonatkozást és a linearitást jelöli. Vö. Hirsch 2014 
az albumszerü szerkezet megfelelö, ha nem éppen elengedhetetlen az új típusú, nyitott adatbázisok működéséhez.

A már említett organizmusszerü felépítés is fontos jellemzője az új típusú dokumentációnak. Ahogyan Gadó Flóra a Nyitott Múzeum Élö archivum szócikkében (2018) fejtegeti, az új típusú archívum immár nem „egyirányú" adatgyüjtésen alapul, hanem egy tudáscserén alapuló modellt alkot. Mint írja, a nyitott, performatív archívum kapcsán Kate Theimer íróra, szerkesztőre referálnak a legtöbben: Theimer az elképzelését a már említett tudásmegosztásra és -cserére alapozza. Minderre az online teret tartja a legmegfelelőbb platformnak. Nála is megjelenik a demokratizálódás és nyitottá tétel olyan formában, hogy szerinte olyan egyéneknek érdemes tudásukat és hozzáértésüket adni, akik nem feltétlenül az adott kérdés szakértői, de tudásuk ennek ellenére mégis releváns a gyüjtemény építése szempontjából (Huvila 2011); „ezek az archívumok egyfajta »ellenarchívumként" tudnak működni. Abban az értelemben, hogy az archívumokból feltáruló hiányokra, titkokra, elnyomott/ elhallgatott történetekre és helyzetekre reflektálnak, amelyek sokszor nem véletlenül szorultak ki a hivatalos rendszerekből” (Gadó 2018).

Általánosságban kijelenthető, hogy az új típusú archívum legfőbb jellemzője a rugalmasság a szó minden értelmében - moduláris felépítéséből adódóan albumszerűen alakítható, valamint a tudáscserére támaszkodva önbővítő módon, organizmusszerűen működik.

\section{A Registry és a digitális fordulat ${ }^{14}$}

A fentiek alapján megállapítható, hogy a COURAGE digitális adatbázisa több szempontból és értelemben is ellenarchívumként működik: mind működése, mind pedig a feldolgozott anyagok alapján. Ahogyan Theimer is írja, a legkézenfekvőbb ennek kialakítására az elektronikus, online tér.

A digitális technológia területhódításával és a tudományos életben való felértékelődésével egyre

14 lásd még: Csurgó Bernadett, Gárdos Judit, Kerényi Szabina, Kovács Éva, Micsik András: The Registry: Empirical and Epistemological Analyses. In Apor Balázs, Apor Péter, Horváth Sándor ed. The Handbook of COURAGE: Cultural Opposition and Its Heritage in Eastern Europe. Budapest, Magyar Tudományos Akadémia Bölcsészettudományi Kutatóközpont Történettudományi Intézet, 2018., különösen 27-29. inkább megkérdőjeleződik a gyüjtemények status quo-ja - az elektronikus hozzáférhetőség demokratizál, kiterjeszti a részvételi lehetőségeket és határokat, elérhetővé teszi a megosztás, az információcsere és a releváns visszajelzés (feedback) egy sokrétü és közösen alakítható platformját. „Tehát a csak olvasáson és szövegen alapuló paradigmát felváltja egy generatív és részvételen alapuló befogadási mód (dynarchive), és ehhez kapcsolódik az audiovizuális online archívumok megjelenése is" (Gadó 2018). Látható tehát, hogy maga a gyüjteményekhez való hozzáférés demokratizálódása több oldalról is vizsgálható - a digitális kontextus hatásai ilyen értelemben az új típusú archívumok organizmusszerű működésével.

A Registry elemeit külön aloldalakon érhetjük el, tematikusan csoportosítva gyüjteményekre (566), szervezetekre (558), fontos személyekre (1090) és eseményekre (867). ${ }^{15}$ (Amellett találunk egy „Ajánlott tételek” elnevezésű fület - az viszont nem világos, hogy mi alapján kerültek ez alá a vonatkozó elemek). Természetesen az aloldalakon belül számos kritérium szerint szűkíthetünk a keresésünkön. Az egyes találatok (tételek) leírásában kereszthivatkozásokként szerepelnek a kapcsolódó tételek, így könnyítve meg a kereső számára a kutatott téma minél szélesebb körủ körbejárhatóságát: ilyen értelemben az adott találathoz számos különböző elérési útvonal vezethet - ezek pedig mindkét irányba mủködnek. A Registry így pontosan olyan komplex és heterogén, mint a COURAGE projekt egésze, illetve a vizsgálódás fókuszát képező civil ellenállás. Sokban eltér a legtöbb hagyományos archívumtól, többek között amiatt is, mert kollektív hozzáférhetőségen és ezáltal egyfajta önbővítő működésen alapul (Csurgó és mtsai 2018). Másrészről pedig a vizsgálódása alá vonja feldolgozott gyüjtemények kiváltotta kulturális és egyéb gyakorlatokat is, így sokkal több, mint puszta nyilvántartás. ${ }^{16}$

Minden - akár új típusú! - archívum esetében fontos észben tartanunk, hogy bármennyire is jelen van a törekvés a történetírás monopóliumának felszámolására, a dokumentáció esetlegessége, a „nemválasztás” jelensége ${ }^{17}$ ebben az esetben is releváns. Ilyen értelemben mondhatnánk azt is, hogy a helyzet lényegében változatlan az archívumi

15 Ezek a 2020. május 12-i számadatok, amelyek időközben változhatnak a Registry esetleges bővülése miatt.

16 http://cultural-opposition.eu/activities/collections/

17 Bármennyire „nyitott” is a gyűjtés és a kiválasztás folyamata, ezzel mindenképpen együtt jár bizonyos elemek „nemválasztása”. 
fordulatot megelőző állapothoz képest, csupán a kiválasztást végző elit réteg cserélődött le. Azonban a COURAGE ebből a szempontból is unikális: egyrészt a projektben résztvevő kutatók és egyéb szakmabeliek eltérő szakmai hátteréből adódott a komplex, interdiszciplináris megközelítés, amely biztosította a vizsgálódás számos tudományterületre kiterjedő fókuszát, másrészt pedig az adatbázis bővítésének lehetőségét bárki számára nyitottá tették - sőt, a hivatalos honlapon bátorítják is erre a digitális adatbázis látogatóit. Ilyen értelemben a Registry (és a projekt egésze is) maradéktalanul mutatja be és teszi láthatóvá a kulturális ellenállás legkülönfélébb jelenségeit.

\section{Összegzés}

A COURAGE által feldolgozott téma megközelítésének komplexitása, illetve a projekt számos eltérő komponensből való felépítettsége az új típusú hozzáférhetőséget, azaz a láthatóságot teszi lehetővé. Az adatbázis, azaz az online kölcsönhatások tára véleményem szerint - az apró, könnyen javítható hibáktól eltekintve - az új típusú nyitott, performatív archívum minden „kitételének” megfelel, ha épp nem túlszárnyalja azokat: az adatgyüjtés és -prezerválás ebben az esetben is úgynevezett tudáscserén alapul, valamint mind a bővíthetőségre, mind pedig a kutatás tárgyára (korábban perifériára szorult jelenségek lévén) jellemző a demokratizáló tendencia. Az archívumok esetében eredendő paradoxont - a „nemválasztás” jelenségét - bár nem oldja fel teljesen, de a törekvés rá mindenképpen értékelendő: ugyanis platformot kínál mindenkinek a bővítéssel kapcsolatos javaslattételre.

Bár a kritikai kultúrakutatás, valamint általában véve a kultúrafókuszú megközelítés elengedhetetlenül fontos lenne a múlt és a kortárs diskurzusban, Magyarországon még mindig nem intézményesült mint módszertan - sőt, művelőivel kapcsolatban egy igencsak marginális csoportról beszélhetünk hazánkban a mai napig. Ezért nagyon fontos a láthatóság megteremtése: minél nagyobb réteg számára válik ismertté egy jelenség, egy gyüjtemény vagy egy archívum, annál biztosabban alakul ki igény az adott irányú vizsgálódásra (ebben az esetben fóként a középiskolás diákok, az egyetemi hallgatók, illetve a fiatal kutatók megcélzásával).

Összességében a COURAGE nemcsak tematikájának és felépítésének komplexitásában egyedülálló, de véleményem szerint követendő példát állít az olyan irányú törekvések elé, amelyek a kritikus, kultúrafókuszú kutatást szorgalmazzák - ez ugyanis elengedhetetlenül szükséges nemcsak a múltbeli, de a kortárs kulturális, szociológiai és (fóként a részvételi) művészeti diskurzus átfogóbb megértéséhez és megfelelő archiválásához, hozzáférhetővé tételéhez.

\section{Felhasznált irodalom}

András Edit 2009 Emlékezés- és/vagy felejtésdiskurzus. In András Edit Kulturális átöltözés Müvészet a szocializmus romjain. Argumentum, Budapest, 143-164.

Apor Balázs - Apor Péter - Horváth Sándor Scheibner Tamás 2018 Cultural Opposition: Concepts and Approaches. In Apor Balázs - Apor Péter - Horváth Sándor eds. The Handbook of COURAGE: Cultural Opposition and Its Heritage in Eastern Europe. Magyar Tudományos Akadémia Bölcsészettudományi Kutatóközpont Történettudományi Intézet, Budapest, 9-26.

Csurgó Bernadett - Gárdos Judit - Kerényi Szabina - Kovács Éva - Micsik András 2018 The Registry: Empirical and Epistemological Analyses. In Apor Balázs - Apor Péter - Horváth Sándor eds. The Handbook of COURAGE: Cultural Opposition and Its Heritage in Eastern Europe. Magyar Tudományos Akadémia Bölcsészettudományi Kutatóközpont Történettudományi Intézet, Budapest, 27-49.

Dessewffy Tibor 1996 Alice Csodaországban, avagy a kultúrakutatás a huszonegyedik században. Imago, (1) 1:9-17.

Havasréti József 2005 A kaleidoszkópon kívül/belül - a kritikai kultúrakutatás Magyarországon. Helikon - Irodalomtudományi Szemle, (51) 1-2:149-164.

Hirsch, Marianne 2014 Az utóemlékezet archívumi fordulata. Helikon, (60) 3:421-437.

Kunt Ernő - Szarvas Zsuzsa 1993 A komplex kultúrakutatás dilemmái a mai Magyarországon. Miskolci Egyetem Kulturális és Vizuális Antropológiai Tanszéke, Miskolc.

Túry György 2016 A kultúra felfalja saját gyermekeit, avagy paradigmák a kultúraelméletben a hatvanas évektől napjainkig. Replika, (27) 98:105-117. 
Vajda András 2017 Az archívum mint a kulturális emlékezet és az örökségképzés színtere. In Jakab Albert Zsolt - Vajda András eds. Örökség, archivum és reprezentáció. Kriza János Néprajzi Társaság, Kolozsvár, 11-28.

Vörös Miklós - Nagy Zsolt 1995 Kultúra és politika a mindennapi életben. Replika, (6.) 17-18:153-156.

\section{Internetes források}

(Letöltés: 2020. május 6.)

Council of the European Union 2018 Draft Council conclusions on the Work Plan for Culture 2019-2022. http://data.consilium. europa.eu/doc/document/ST-13948-2018INIT/en/pdf\#http://data.consilium.europa.eu/ doc/document/ST-13948-2018-INIT/en/pdf

COURAGE. Gyűjtemények hálózata (é.n.) Collections (Registry). http://culturalopposition.eu/activities/collections/

COURAGE. Gyűjtemények hálózata (é.n.) Courage Games. http://cultural-opposition.eu/ games/

COURAGE. Gyűjtemények hálózata (é.n.) COURAGE-PAREVO Nemzetközi Dokumentumfilm-fesztivál. http://hu.culturalopposition.eu/activities/film-festival/

COURAGE. Gyűjtemények hálózata (é.n.) Kiállítás. http://cultural-opposition.eu/courage/ exhibition?lang=hu
COURAGE. Gyűjtemények hálózata (é.n.) Registry. http://hu.cultural-opposition.eu/ registry/

COURAGE. Gyüjtemények hálózata (é.n.) Rólunk. http://hu.cultural-opposition.eu/\#project

COURAGE. Gyüjtemények hálózata (é.n.) Tananyag. http://hu.cultural-opposition.eu/ learning/

European Commission (é.n.): Horizon 2020. What is Horizon 2020? https:// ec.europa.eu/programmes/horizon2020/en/ what-horizon-2020

Gadó Flóra 2018 Élő archívum. /Néprajzi Múzeum/, Nyitott Múzeum, http://nyitottmuzeum. neprajz.hu/szocikkek/elo_archivum

Huvila, Isto 2011. What is a participatory archive? For real (?). Isto Huvila, http://www.istohuvila. se/what-participatory-archive-real

Rés A Présen 2018. Készül már a tananyag is. $M a-$ gyar Narancs, 2018. 28. Magyar Narancs, https://magyarnarancs.hu/lokal/ keszul-mar-a-tananyag-is-112347

Sóki Diána 2018. COURAGE - Gyűjtemények hálózata - Interjú Kovács Évával és Erőss Nikolettel. Magyar Múzeumok, https://www.magyarmuzeumok.hu/cikk/ courage-gyujtemenyek-halozata 